\title{
Inhibition of IgE-dependent Mouse Triphasic Cutaneous Reaction by a Boiling Water Fraction Separated from Mycelium of Phellinus linteus
}

\section{Naoki Inagaki ${ }^{1}$, Tomonori Shibata ${ }^{1}$, Tomokazu Itoh ${ }^{1}$, Tomohiro Suzuki ${ }^{2}$, Hiroyuki Tanaka ${ }^{1}$, Tomoyuki Nakamura ${ }^{3}$, Yukihito Akiyama ${ }^{3}$, Hirokazu Kawagishi ${ }^{2}$ and Hiroichi Nagai ${ }^{1}$}

${ }^{1}$ Department of Pharmacology, Gifu Pharmaceutical University, Gifu, ${ }^{2}$ Department of Applied Biological Chemistry, Faculty of Agriculture, Shizuoka University, Shizuoka and ${ }^{3}$ Applied Fungi Institute, IBI Corporation, Yamanashi, Japan

\begin{abstract}
Phellinus linteus, a mushroom, contains constituents that exhibit potent antitumor effects through activating immune cells. Recently, anti-inflammatory and anti-allergic properties of $P$. linteus extracts have also been implicated. In the present study, therefore, we separated the constituents of mycelium of $P$. linteus into five fractions-chloroform-soluble (CF), ethyl acetate-soluble (EA), methanolsoluble (AE), water-soluble (WA) and boiling water-soluble (BW) fractions-and examined their suppressive effects on the IgE-dependent mouse triphasic cutaneous reaction. The triphasic reaction was induced in the ear of BALB/c mice passively sensitized with anti-dinitrophenol IgE by painting with 2,4-dinitrofluorobenzene $24 \mathrm{~h}$ later. Ear swelling appeared triphasically with peak responses at $1 \mathrm{~h}$, $24 \mathrm{~h}$ and 8 days after the challenge. ME, WA and BW given orally at a dose of $100 \mathrm{mg} \mathrm{kg}^{-1}$ significantly inhibited the first and second phase ear swelling, and $\mathrm{BW}$ also inhibited the third phase response. $\mathrm{CF}$ only inhibited the second phase. The inhibition by BW was the most potent and almost dose-dependent at doses of $30-300 \mathrm{mg} \mathrm{kg}^{-1}$. BW also inhibited vascular permeability increase caused by passive cutaneous anaphylaxis and histamine, and ear swelling caused by tumor necrosis factor- $\alpha$. In contrast, BW apparently potentiated the production of interleukin-4 and interferon- $\gamma$ from anti-CD3-stimulated mouse splenocytes. These results indicate that BW derived from mycelium of $P$. linteus contains some constituents with anti-allergic as well as immunopotentiating properties.
\end{abstract}

Keywords: allergic reaction - boiling - IgE - mouse - mycelium - Phellinus linteus - water fraction

\section{Introduction}

Phellinus linteus, a mushroom, has been known to exhibit a potent antitumor activity and polysaccharides involved are considered to be the active constituents (1-4). The antitumor activity of $P$. linteus has been ascribed to an immunopotentiating effect because $P$. linteus polysaccharides exhibit activating effects on immune cells such as T lymphocytes, B lymphocytes, natural killer cells, macrophages and dendritic cells (5-8). Recently, direct mechanisms for the antitumor activities of $P$. linteus have also been recognized $(9,10)$.

For reprints and all correspondence: Hiroichi Nagai, PhD, Department of Pharmacology, Gifu Pharmaceutical University, 5-6-1 Mitahorahigashi, Gifu 502-8585, Japan. Tel/Fax: +81-58-237-8584; E-mail: nagai@gifu-pu.ac.jp
In contrast to the immunopotentiating properties of $P$. linteus, anti-inflammatory and anti-allergic properties of $P$. linteus have rarely been investigated. In 2004, Kim et al. (11) reported that $n$-butanol fraction of $P$. linteus dosedependently inhibits croton oil-induced mouse ear edema. In 2003, Kim et al. (12) reported that oral administration of proteoglycan isolated from P. linteus inhibits collagen-induced mouse arthritis and that the inhibition is associated with reduced serum IgG1 and IgG2a levels and reduced production of tumor necrosis factor- $\alpha$ (TNF- $\alpha$ ) and interferon- $\gamma$ (IFN- $\gamma$ ) in lymph node cells. Furthermore, P. linteus extract reduces IgE production that may be associated with increased IFN- $\gamma$ production (13). These reports strongly suggest that $P$. linteus possesses anti-allergic and/or anti-inflammatory properties as well as immunomodulating properties.

(C) The Author (2005). Published by Oxford University Press. All rights reserved.

The online version of this article has been published under an open access model. Users are entitled to use, reproduce, disseminate, or display the open access version of this article for non-commercial purposes provided that: the original authorship is properly and fully attributed; the Journal and Oxford University Press are attributed as the original place of publication with the correct citation details given; if an article is subsequently reproduced or disseminated not in its entirety but only in part or as a derivative work this must be clearly indicated. For commercial re-use, please contact journals.permissions@oupjournals.org 
In the present study, therefore, we fractionated the constituents of cultured mycelium of $P$. linteus (4) and examined the anti-allergic properties using the IgE-dependent mouse triphasic cutaneous reaction $(14,15)$.

\section{Methods}

\section{Mice}

Male and female BALB/c and male ddY mice, 6 weeks of age, were obtained from Japan SLC Inc. (Hamamatsu, Japan) and maintained for 2 weeks before the start of experiments. They were housed in an air-conditioned animal room with a temperature of $22 \pm 1{ }^{\circ} \mathrm{C}$ and a humidity of $60 \pm 5 \%$, and fed laboratory diet and water ad libitum. Experiments were undertaken following the guidelines for the care and use of experimental animals of the Japanese Association for Laboratory Animal Science (1987) (16) with an approval by the committee of our university.

\section{Fractionation of Mycelium of $P$. linteus}

Mycelium of $P$. linteus (strain PL-08, IBI Co., Ltd, Yamanashi, Japan) cultured in a medium (4\% glucose, $0.3 \%$ dried yeast extract, $0.3 \%$ polypeptone, $0.05 \%$ potassium dihydrogenphosphate, $0.05 \%$ disodium hydrogenphosphate, $\mathrm{pH} 5.5$ ) was separated by centrifugation and dried (4). Constituents of the dried mycelium were extracted sequentially with chloroform (CF), ethyl acetate (EA), methanol (ME), water (WA) and boiling water $(\mathrm{BW})$, and then the fractions were freeze-dried. The procedure and amount of each fraction obtained are summarized in Fig. 1. The fractions were dissolved or suspended in water and administered to mice orally.

\section{Drugs and Reagents}

As reference drugs, prednisolone (sodium succinate, Shionogi \& Co., Ltd, Osaka, Japan) and diphenhydramine (hydrochloride, Sigma-Aldrich Co., St Louis, MO, USA) were used. They were prepared in water and administered to mice orally. For causing cutaneous reactions, histamine (dihydrochloride, Nacalai Tesque, Inc., Kyoto, Japan) and TNF- $\alpha$ (Techne Co., Minneapolis, MN, USA) were used. Anti-CD3 antibodies (anti-mouse CD3 $\varepsilon$ hamster IgG) were purchased from eBioscience, Inc. (San Diego, CA, USA).

\section{IgE and Antigens}

Mouse anti-dinitrophenol (DNP) monoclonal IgE was obtained by culturing IgE-producing cells, EC-1, as reported previously (17). IgE titer of the preparation was 1:1024 as estimated by passive cutaneous anaphylaxis (PCA) in rats. For the induction of IgE-dependent cutaneous reactions, 2,4-dinitrofluorobenzene (DNFB, Nacalai Tesque) and DNP-conjugated bovine serum albumin (DNP-BSA) were used.

\section{IgE-dependent Triphasic Cutaneous Reaction in the Mouse Ear}

IgE-dependent triphasic cutaneous reaction in the ear of female BALB/c mice was induced as reported previously $(14,15,17)$. In brief, mice were passively sensitized by injecting $1 \mathrm{ml}$ of mouse anti-DNP monoclonal IgE preparation intravenously. Twenty-four hours later, cutaneous reaction was evoked by painting with $25 \mu \mathrm{l}$ of $0.15 \%$ DNFB acetone-olive oil $(3: 1)$ solution onto each surface of both ear lobes. Ear thickness was measured before and after the DNFB challenge using a micrometer (Ozaki MFG Co., Ltd, Tokyo, Japan).

\section{PCA in the Mouse Ear}

PCA was induced in the ear of male ddY mice as reported previously $(18,19)$. Appropriately diluted mouse anti-DNP monoclonal IgE preparation at a volume of $10 \mu \mathrm{l}$ was injected into both ear lobes for sensitization. Twenty-four hours later, $0.25 \mathrm{ml}$ of $0.1 \mathrm{mg} \mathrm{ml}^{-1}$ DNP-BSA saline solution containing

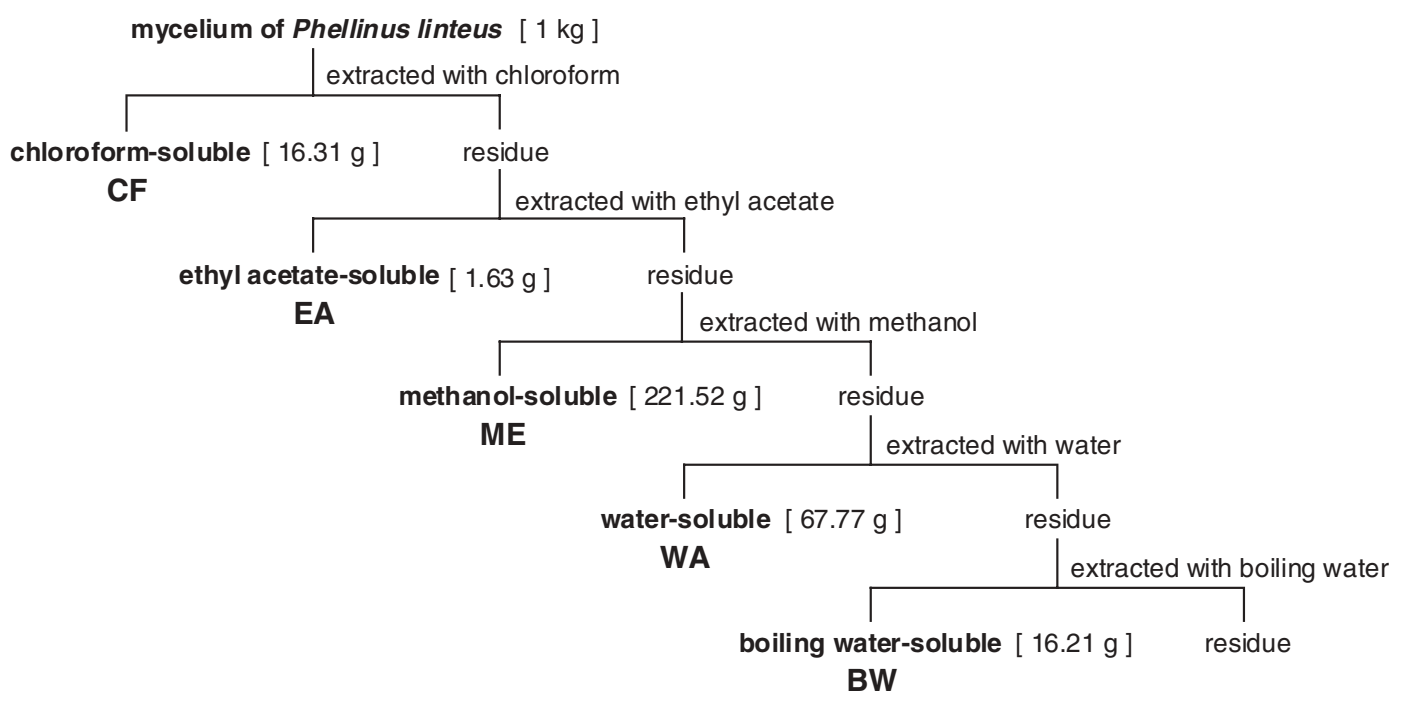

Figure 1. Fractionation of constituents of mycelium of $P$. linteus and the amount of each fraction obtained. 
0.5\% Evans blue was injected intravenously. Vascular permeability increase in the ear was assessed by measuring the amount of extravasated dye $30 \mathrm{~min}$ after the challenge.

\section{Cutaneous Reactions Caused by Histamine and TNF- $\alpha$ in the Mouse Ear}

Histamine-induced vascular permeability increase was observed in the ear of male ddY mice $(18,20)$. In brief, $10 \mu \mathrm{l}$ of $10^{-4} \mathrm{~g} \mathrm{ml}^{-1}$ histamine saline solution was injected into both ear lobes. At the same time, $0.25 \mathrm{ml}$ of $0.5 \%$ Evans blue saline solution was injected intravenously. The amount of extravasated dye for $30 \mathrm{~min}$ after the histamine injection was measured.

TNF- $\alpha$-induced cutaneous reaction was observed in the ear of male BALB/c mice (21). Ten microliters of $10^{-5} \mathrm{~g} \mathrm{ml}^{-1}$ TNF- $\alpha$ saline solution was injected into both ear lobes and the increase in ear thickness was assessed $24 \mathrm{~h}$ later using a micrometer.

\section{Cytokine Production in Mouse Splenocytes}

Spleen was excised from intact male BALB/c mice and splenocytes were suspended in RPMI-1640 medium supplemented with fetal calf serum at $10 \%$. Splenocytes at a concentration of $2.5 \times 10^{6}$ cells ml ${ }^{-1}$ were incubated for $48 \mathrm{~h}$ in the presence of $1.5 \mu \mathrm{g} \mathrm{ml}^{-1}$ anti-CD3 antibodies. After the incubation, interleukin-4 (IL-4) and IFN- $\gamma$ in the supernatant were quantified using commercial enzyme-linked immunosorbent assay kits (Endogen Inc., Woburn, MA, USA), and viable cells were counted.

\section{Statistics}

Results were expressed as the mean \pm SEM. Statistical evaluation of data was performed using InStat Program (GraphPad Software, San Diego, CA, USA). Comparison of data among three or more groups was performed using Dunnett's or Dunn's multiple comparison test after confirming the variance of data by Bartlet's test. Comparison of data between two groups was performed by Student's or Welch's $t$-test based on the variance of data examined by $F$-test. When the $P$-value was $<0.05$ the difference was considered to be significant.

\section{Results}

\section{Inhibition of Triphasic Cutaneous Reaction by Fraction BW Derived from $P$. linteus}

Effects of five fractions-CF, EA, ME, WA and BW-on the triphasic cutaneous reaction were investigated. The fractions and prednisolone were administered orally 1 and $2 \mathrm{~h}$, respectively, before DNFB challenge. The dose for fractions was $100 \mathrm{mg} \mathrm{kg}^{-1}$ except for EA, which was given at a dose of $50 \mathrm{mg} \mathrm{kg}^{-1}$ because of the limited amount obtained. Results are shown in Fig. 2. Upon challenge with DNFB, ear swelling appeared triphasically with peak responses at $1 \mathrm{~h}, 24 \mathrm{~h}$ and 8 days after the challenge. ME, WA and BW at a dose of $100 \mathrm{mg} \mathrm{kg}^{-1}$ significantly inhibited the first and second phase ear swelling, and BW also inhibited the third phase response. $\mathrm{CF}$ at a dose of $100 \mathrm{mg} \mathrm{kg}^{-1}$ inhibited only the second phase response. Prednisolone at a dose of $5 \mathrm{mg} \mathrm{kg}^{-1}$ inhibited all three phase responses potently. As the inhibition by ME, $\mathrm{WA}, \mathrm{BW}$ and prednisolone in the first phase response and prednisolone in the second phase response was expressed potently, the ear thickness was reduced under the prevalue.

Results of a dose-response study on BW are indicated in Fig. 3. BW at doses of $30-300 \mathrm{mg} \mathrm{kg}^{-1}$ was given orally $1 \mathrm{~h}$ before challenge. BW inhibited all three phases almost dose-dependently. Prednisolone given $2 \mathrm{~h}$ before inhibited the three phases significantly.

\section{Inhibition of PCA and Histamine-induced Cutaneous Reaction by BW}

Effects of BW on vascular permeability increase associated with PCA and caused by histamine were investigated. BW and diphenhydramine were administered orally $1 \mathrm{~h}$ and $30 \mathrm{~min}$, respectively, before eliciting the reaction. Results of PCA are

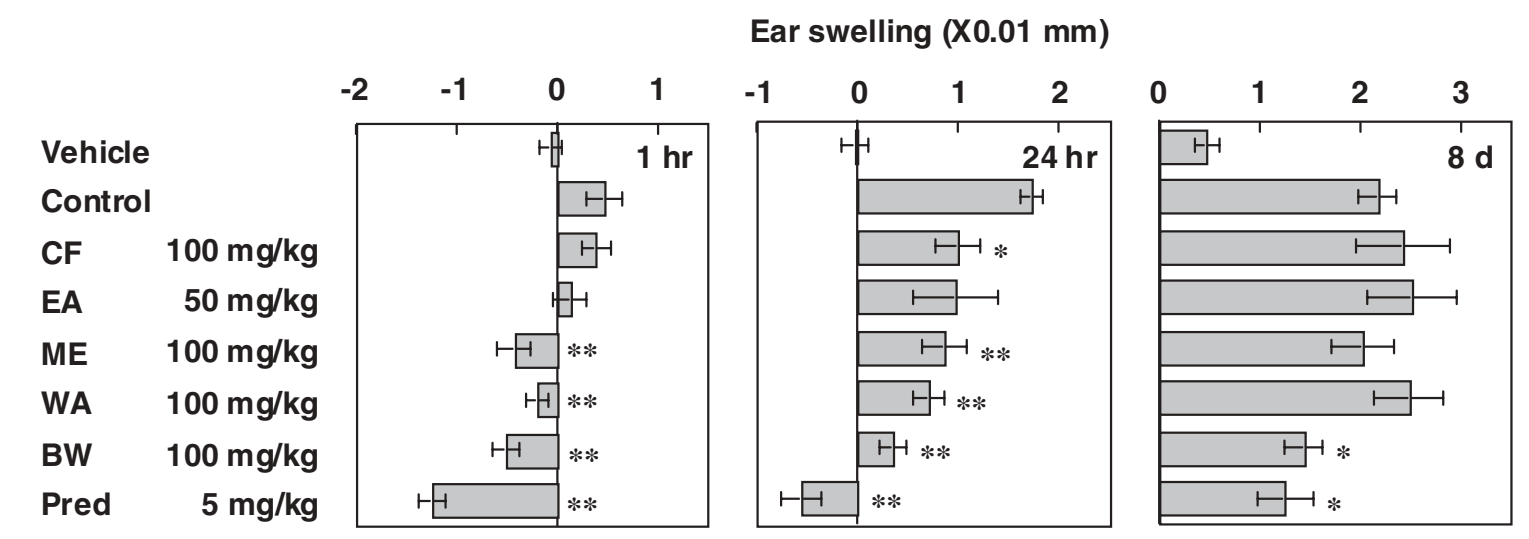

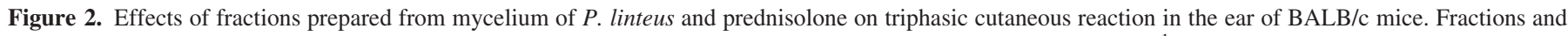

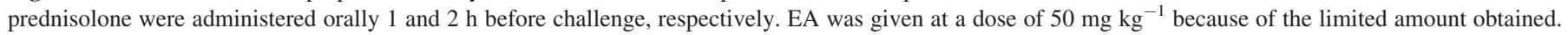
Each value represents the mean \pm SEM for seven or eight mice. ${ }^{*} P<0.05,{ }^{*} P<0.01$. 
Ear swelling $(X 0.01 \mathrm{~mm})$

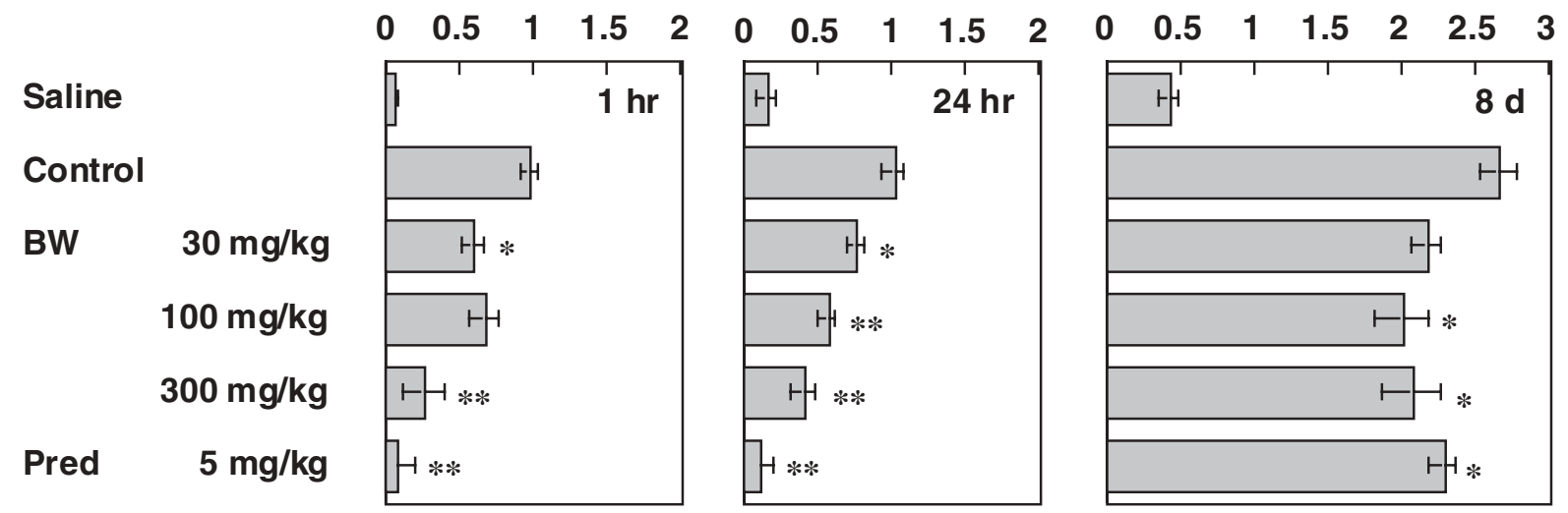

Figure 3. Effects of fraction BW and prednisolone on triphasic cutaneous reaction in the ear of BALB/c mice BW and prednisolone were administered orally 1 and $2 \mathrm{~h}$ before challenge, respectively. Each value represents the mean \pm SEM for seven or eight mice. $* P<0.05, * * P<0.01$.
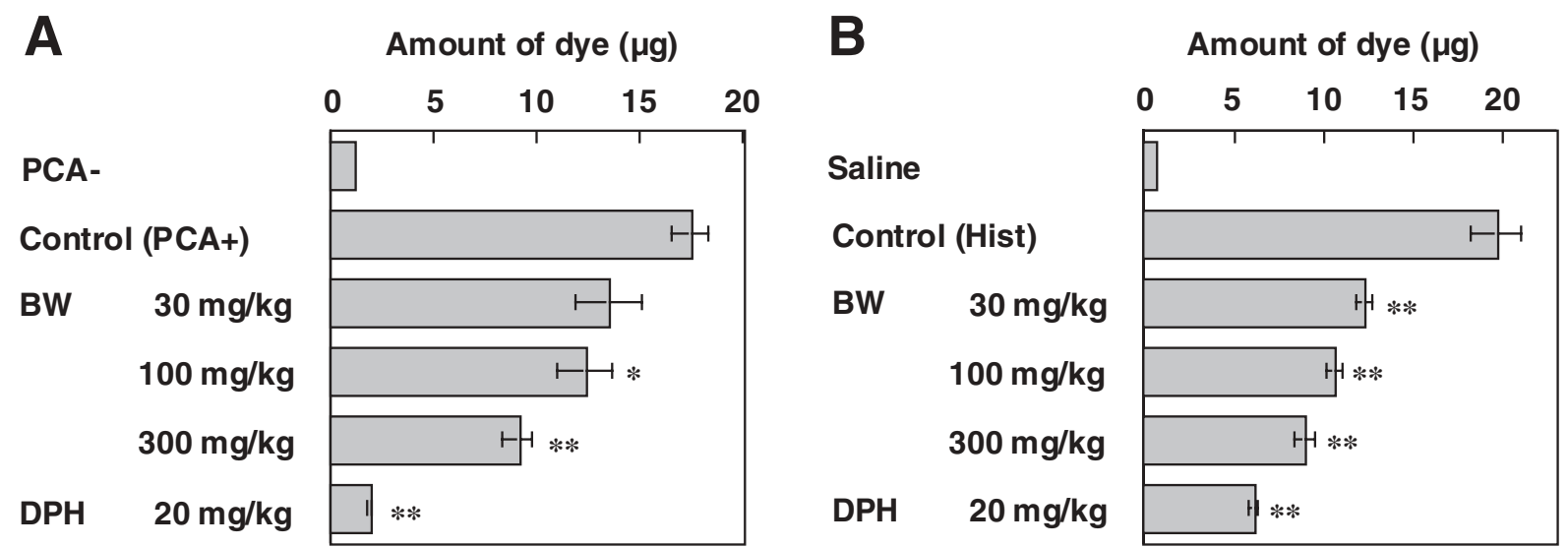

Figure 4. Effects of fraction BW and diphenhydramine on vascular permeability increase caused by PCA and histamine in male ddY mice. Vascular permeability increase was cause by PCA (A) and histamine injection (B) in the mouse ear. BW and diphenhydramine were administered orally $1 \mathrm{~h}$ and $30 \mathrm{~min}$, respectively, before eliciting the reaction. Each value represents the mean \pm SEM for three or seven mice. $* P<0.05, * * P<0.01$.

indicated in Fig. 4A. BW at 30-300 $\mathrm{mg} \mathrm{kg}^{-1}$ inhibited the vascular permeability increase dose-dependently. As shown in Fig. 4B, histamine-induced vascular permeability increase was also inhibited by BW dose-dependently. Diphenhydramine at a dose of $20 \mathrm{mg} \mathrm{kg}^{-1}$ inhibited the vascular permeability increase associated with PCA and induced by histamine injection potently.

\section{Inhibition of TNF- $\alpha$-induced Cutaneous Reactions by BW}

Effects of BW on TNF- $\alpha$-induced ear swelling were investigated. Injection of TNF- $\alpha$ into the ear lobe of mice caused an ear swelling with a peak response at $\sim 24 \mathrm{~h}$ later. BW and prednisolone were administered $1 \mathrm{~h}$ before TNF- $\alpha$ injection. As shown in Fig. 5, BW at doses of 30 and $300 \mathrm{mg} \mathrm{kg}^{-1}$ inhibited the ear swelling significantly and at $100 \mathrm{mg} \mathrm{kg}^{-1}$ a tendency of inhibition was observed. Prednisolone at a dose of $5 \mathrm{mg} \mathrm{kg}^{-1}$ potently inhibited the TNF- $\alpha$-induced ear swelling.
Ear swelling (X0.01 mm)

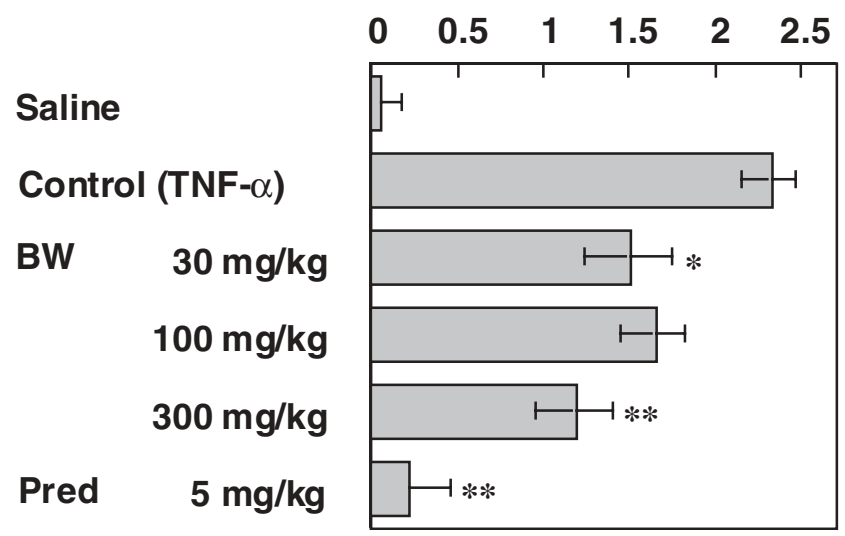

Figure 5. Effects of fraction BW and prednisolone on ear swelling caused by TNF- $\alpha$ in male BALB/c mice BW and prednisolone were administered orally 1 $\mathrm{h}$ before TNF- $\alpha$ injection. Each value represents the mean \pm SEM for seven mice. $* P<0.05, * * P<0.01$. 


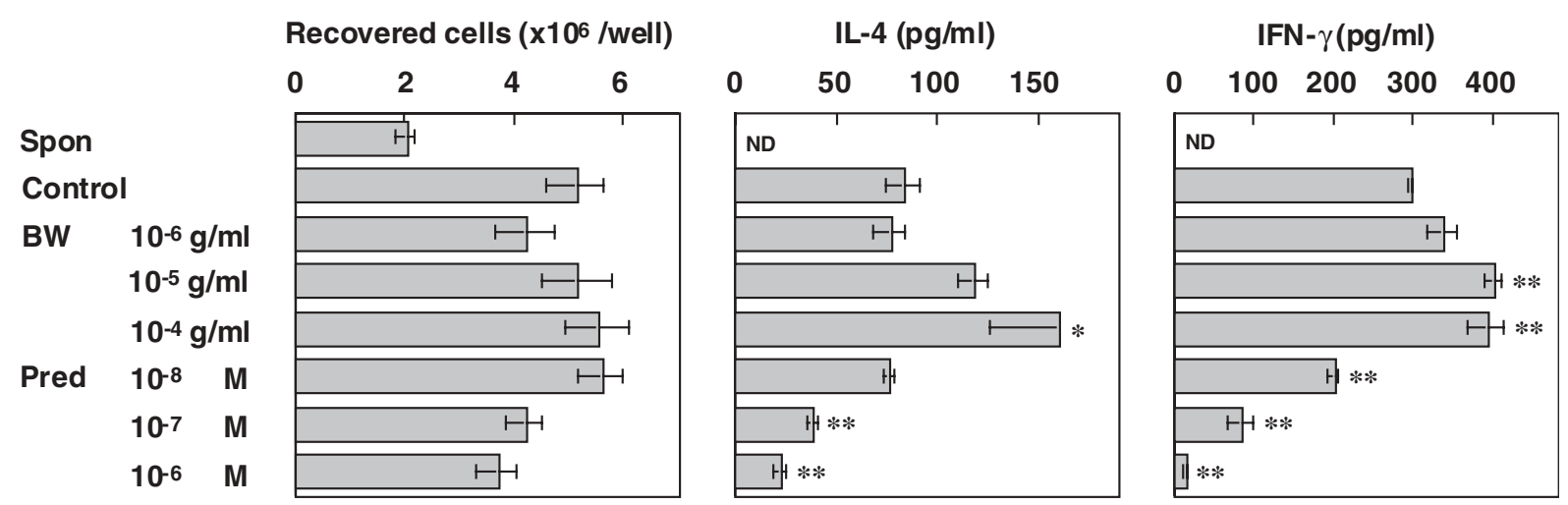

Figure 6. Effects of fraction BW and prednisolone on cytokine production in mouse splenocytes. Splenocytes were incubated with anti-CD3 antibodies for $48 \mathrm{~h}$ in duplicate. After the incubation, cells were recovered and counted. IL-4 and IFN- $\gamma$ in the supernatants were quantified by enzyme-linked immunosorbent assay. Each value represents the mean \pm SEM for four mice.

\section{Potentiation of Cytokine Production in Splenocytes by BW}

Effects of BW on anti-CD3-induced cytokine production in mouse splenocytes were investigated. Splenocytes, $2.5 \times$ $10^{6}$ cells per well, were incubated for $48 \mathrm{~h}$ in the presence of anti-CD3 antibodies. BW at concentrations from $10^{-6}$ to $10^{-4} \mathrm{~g} \mathrm{ml}^{-1}$ and prednisolone at concentration from $10^{-8}$ to $10^{-6} \mathrm{M}$ were added to wells $1 \mathrm{~h}$ before addition of anti-CD3 antibodies. As shown in Fig. 6, during the incubation period, although the number of viable cells reduced to $80 \%$ in the absence of anti-CD3 antibodies, anti-CD3 stimulation caused an increase in cell number $\sim 2$-fold. Incubation with BW did not affect the increase, but prednisolone showed a tendency of concentration-dependent inhibition. Anti-CD3 stimulation induced IL- 4 and IFN- $\gamma$ production in splenocytes. BW potentiated the production of both cytokines in a concentrationdependent manner, and the potentiation was apparent at concentrations of $10^{-5}$ and $10^{-4} \mathrm{~g} \mathrm{ml}^{-1}$. In contrast, prednisolone potently inhibited the anti-CD3-induced cytokine production in a concentration-dependent manner.

\section{Discussion}

In the present study, we separated the constituents of mycelium of $P$. linteus into five fractions and examined their suppressive effects on the IgE-dependent mouse triphasic cutaneous reaction. Present results clearly indicated that the BW fraction contains constituents responsible for inhibiting all three phases of the cutaneous responses most potently.

In mice systemically sensitized with anti-DNP IgE, ear swelling appears triphasically upon challenge with DNFB $(14,15)$. The first phase ear swelling appears immediately after the challenge. The first phase response is absent in mast cell-deficient WBB6F1-W/W $\mathrm{W}^{\mathrm{v}}$ mice $(17,22)$ and inhibited by antihistamines $(17,23)$, demonstrating that the response is dependent on mast cells and a mast cell mediator, histamine. Fraction BW separated from mycelium of $P$. linteus potently inhibited the vascular permeability increase associated with
PCA and caused by histamine injection. Vascular permeability increase associated with PCA involves IgE-dependent mast cell activation and histamine release, and released histamine is responsible for the increased vascular permeability $(19,20)$. Therefore, BW may suppress IgE-dependent mast cell activation and/or antagonize against histamine actions.

The second phase ear swelling in the triphasic cutaneous reaction peaked at $\sim 24 \mathrm{~h}$ after the challenge is fully expressed in mast cell-deficient mice, and inhibited by antibodies against interleukin-1 $\beta$ (IL-1 $\beta$ ) and TNF- $\alpha(21,24,25)$. IL-1 $\beta$ and TNF- $\alpha$ injected into ear lobes of mice cause ear swelling peaked at $\sim 24 \mathrm{~h}$ later. These results strongly suggest that inflammatory cytokines participate in the induction of the second phase response and that the response could be induced mast cell-independently. In contrast, as mast cells produce inflammatory cytokines, mast cell activation could also participate in inducing the second phase response $(26,27)$. In the present results, fraction BW inhibited the ear swelling caused by TNF- $\alpha$, suggesting that inhibitory properties of BW for inflammatory cytokine actions participate in the inhibition of the second phase response.

The third phase ear swelling in the triphasic cutaneous reaction appears several days later and its peak response is observed at $\sim 8$ days later $(14,15)$. The third phase response is absent in athymic nude mice and partially reduced in mast cell-deficient mice. The third phase ear swelling is characterized by an accumulation of abundant eosinophils. Although a subpopulation of $\mathrm{T}$ lymphocytes seems to play important roles in the induction of the third phase response (15), the precise mechanism is not elucidated. In the present study, BW inhibited the third phase response partially. Inhibition of the first phase response by BW may contribute to its inhibition of the third phase response, but the inhibitory mechanism involved should be examined further.

It is well established that polysaccharides of $P$. linteus potentiate $\mathrm{T}$ cell responses (6). In the present study, we examined the effects of BW on the cytokine production of mouse splenocytes stimulated with anti-CD3 antibodies. It is interesting to note that the fraction BW potentiated the production of both 
Th1 cytokine, IFN- $\gamma$ and Th2 cytokine, IL-4. Therefore, BW may potentiate $\mathrm{T}$ cell cytokine production directly and/or through augmenting accessory cell function, and the results coincide well with the previous reports $(6,8)$. However, the immunopotentiating effects of fraction BW may not support its anti-allergic effects. Therefore, effects of BW on the T cell responses should be further examined using different stimulants in relation to its inhibitory mechanism of the third phase response. As the BW fraction derived from P. linteus mycelium seems to contain high molecular weight watersoluble constituents, such as polysaccharides, polysaccharides of $P$. linteus may exhibit anti-allergic activities as well as immunopotentiating activities.

In summary, we examined the anti-allergic activities of five fractions prepared from mycelium of $P$. linteus using a mouse allergic reaction model and found that the $\mathrm{BW}$-soluble fraction possesses potent anti-allergic activities. Furthermore, the BW fraction also exhibits immunopotentiating activities. Polysaccharides involved in $P$. linteus may be the active constituents in the BW fraction responsible for both anti-allergic activities and immunopotentiating activities. Identification and characterization of the active constituents are now underway.

\section{References}

1. Ikekawa T, Nakanishi M, Uehara N, Chihara G, Fukuoka F. Antitumor action of some basidiomycetes, especially Phellinus linteus. Jpn J Cancer Res (Gann) 1968;59:155-7.

2. Sasaki T, Arai Y, Ikekawa T, Chihara G, Fukuoka F. Antitumor polysaccharides from some polyporaceae, Ganoderma applanatum (Pers.) Pat and Phellinus linteus (Berk. Et Curt) Aoshima. Chem Pharm Bull 1971;19:821-6.

3. Han SB, Lee CW, Jeon YJ, Hong ND, Yoo ID, Yang KH, et al. The inhibitory effect of polysaccharides isolated from Phellinus linteus on tumor growth and metastasis. Immunopharmacol 1999;41:157-64.

4. Nakamura T, Matsugo S, Uzuka Y, Matsuo S, Kawagishi H. Fractionation and anti-tumor activity of the mycelia of liquid-cultured Phellinus linteus. Biosci Biotechnol Biochem 2004;68:868-72.

5. Song KS, Cho SM, Lee JH, Kim HM, Han SB, Ko KS, et al. B-lymphocyte-stimulating polysaccharide from mushroom Phellinus linteus. Chem Pharm Bull 1995;43:2105-8.

6. Kim HM, Han SB, Oh GT, Kim YH, Hong DH, Hong ND, et al. Stimulation of humoral and cell mediated immunity by polysaccharide from mushroom Phellinus linteus. Int J Immunopharmacol 1996;18:295-303.

7. Kim GY, Oh YH, Park YM. Acidic polysaccharide isolated from Phellinus linteus induces nitric oxide-mediated tumoricidal activity of macrophages through protein tyrosine kinase and protein kinase C. Biochem Biophys Res Commun 2003;309:399-407.

8. Park SK, Kim GY, Lim JY, Kwak JY, Bae YS, Lee JD, et al. Acidic polysaccharides isolated from Phellinus linteus induce phenotypic and functional maturation of murine dendritic cells. Biochem Biophys Res Commun 2003;3012:449-58.

9. Li G, Kim DH, Kim TD, Park BJ, Park HD, Park JI, et al. Protein-bound polysaccharide from Phellinus linteus induces G2/M phase arrest and apoptosis in SW480 human colon cancer cells. Cancer Lett 2004;216: $175-81$.
10. Lee HJ, Lee HJ, Lim ES, Ahn KS, Shim BS, Kim HM, et al. Cambodian Phellinus linteus inhibits experimental metastasis of melanoma cells in mice via regulation of urokinase type plasminogen activator. Biol Pharm Bull 2005;28:27-31.

11. Kim SH, Song YS, Kim SK, Kim BC, Lim CJ, Park EH. Anti-inflammatory and related pharmacological activities of the $n-\mathrm{BuOH}$ subfraction of mushroom Phellinus linteus. J Ethnopharmacol 2004;93: 141-6.

12. Kim GY, Kim SH, Hwang SY, Kim HY, Park YM, Park SK, et al. Oral administration of proteoglycan isolated from Phellinus linteus in the prevention and treatment of collagen-induced arthritis in mice. Biol Pharm Bull 2003;26:823-31.

13. Lim BO, Yamada K, Cho BG, Jeon T, Hwang SG, Park T, et al. Comparative study on the modulation of $\mathrm{IgE}$ and cytokine production by Phellinus linteus grown on germinated brown rice, Phellinus linteus and germinated brown rice in murine splenocytes. Biosci Biotechnol Biochem 2004;68: 2391-4.

14. Tahara E, Satoh T, Watanabe C, Shimada Y, Itoh T, Nagai H, et al. A third-phase cutaneous (very late phase) response after elicitation with dinitrofluorobenzene in passively or actively sensitized mice. Allergol Int 1999;48:265-73.

15. Nakamura N, Ochi T, Sawada M, Tanaka H, Inagaki N, Saiki I, et al. Role of $\mathrm{T}$ cells in IgE-dependent triphasic cutaneous reaction caused by dinitrofluorobenzene in the mouse ear: participation of $\mathrm{CD}^{+} \mathrm{T}$ cells. Allergol Int 2003;52:31-6.

16. Japanese Association for Laboratory Animal Science. Guideline for animal experimentation. Exp Anim 1987;36:285-8.

17. Nagai H, Sakurai T, Inagaki N, Mori H. An immunopharmacological study of the biphasic skin reaction in mice. Biol Pharm Bull 1995;18: 239-45.

18. Inagaki N, Goto S, Nagai H, Koda A. Mouse ear PCA as a model for evaluating antianaphylactic agents. Int Arch Allergy Appl Immunol 1984;74:91-2.

19. Inagaki N, Goto S, Nagai H, Koda A. Homologous passive cutaneous anaphylaxis in various strains of mice. Int Arch Allergy Appl Immunol 1986;81:58-62.

20. Inagaki N, Goto S, Yamasaki M, Nagai H, Koda A. Studies on vascular permeability increasing factors involved in 48-hour homologous PCA in the mouse ear. Int Arch Allergy Appl Immunol 1986;80:285-90.

21. Inagaki N, Tsunematsu M, Sakurai T, Matsuo A, Nagai H. Effect of prednisolone on IgE-dependent biphasic cutaneous reaction in BALB/c mice. Gen Pharmacol 1997;28:93-7.

22. Ray MC, Tharp MD, Sullivan TJ, Tigelaar RE. Contact hypersensitivity reactions to dinitrofluorobenzene mediated by monoclonal IgE anti-DNP antibodies. J Immunol 1983;131:1096-102.

23. Inagaki N, Sakurai T, Abe T, Musoh K, Kawasaki H, Tsunematsu M, et al. Characterization of antihistamines using biphasic cutaneous reaction in BALB/c mice. Life Sci 1998;63:PL145-50.

24. Sakurai T, Inagaki N, Nagai $H$. The effect of anti-tumor necrosis factor (TNF)- $\alpha$ monoclonal antibody on allergic cutaneous late phase reaction in mice. Life Sci 1994;54:PL291-5.

25. Nagai H, Sakurai T, Abe T, Matsuo A, Tsunematsu M, Inagaki N. TNF- $\alpha$ participates in an IgE-mediated cutaneous reaction in mast cell deficient, WBB6F1-W/W ${ }^{\mathrm{v}}$ mice. Inflamm Res 1996;45:136-40.

26. Nagai H, Abe T, Yamaguchi I, Mito K, Tsunematsu M, Kimata M, et al. Role of mast cells in the onset of IgE-mediated late-phase cutaneous response in mice. J Allergy Clin Immunol 2000;106:S91-8.

27. Kimata M, Abe T, Yamaguchi I, Mito K, Tsunematsu M, Inagaki N, et al. Prednisolone inhibits an IgE-mediated late-phase allergic cutaneous reaction by interfering with the activation of mast cells in mice. Pharmacology 2001;62:17-22.

Received March 8, 2005; accepted July 3, 2005 


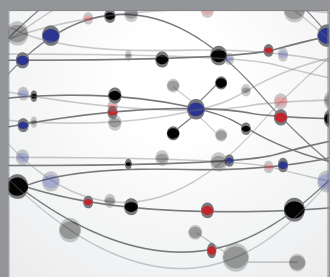

The Scientific World Journal
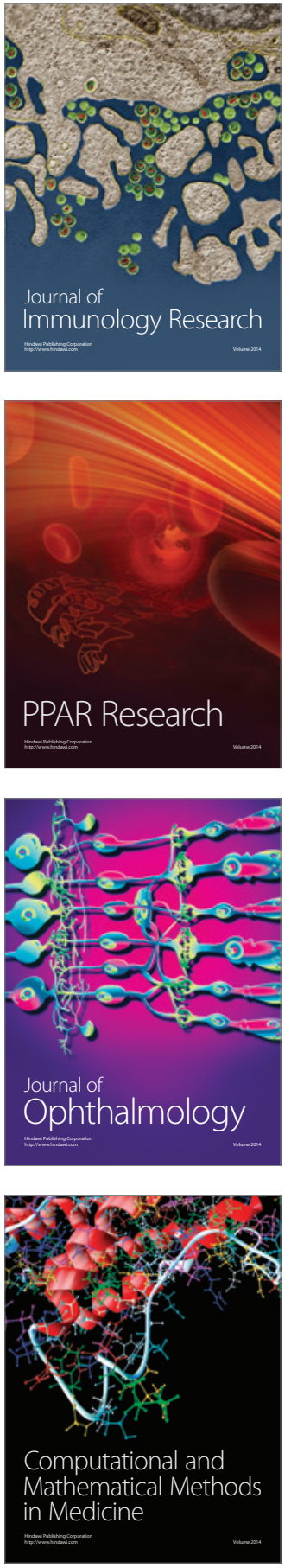

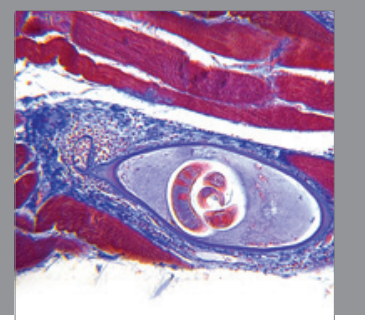

Gastroenterology

Research and Practice
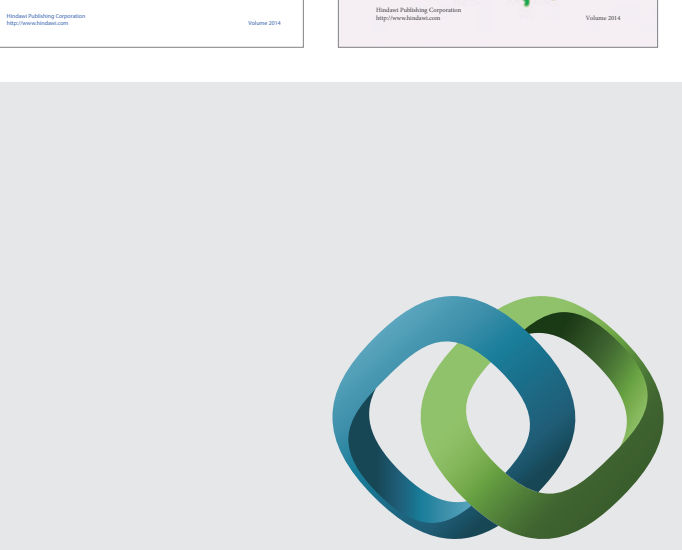

\section{Hindawi}

Submit your manuscripts at

http://www.hindawi.com
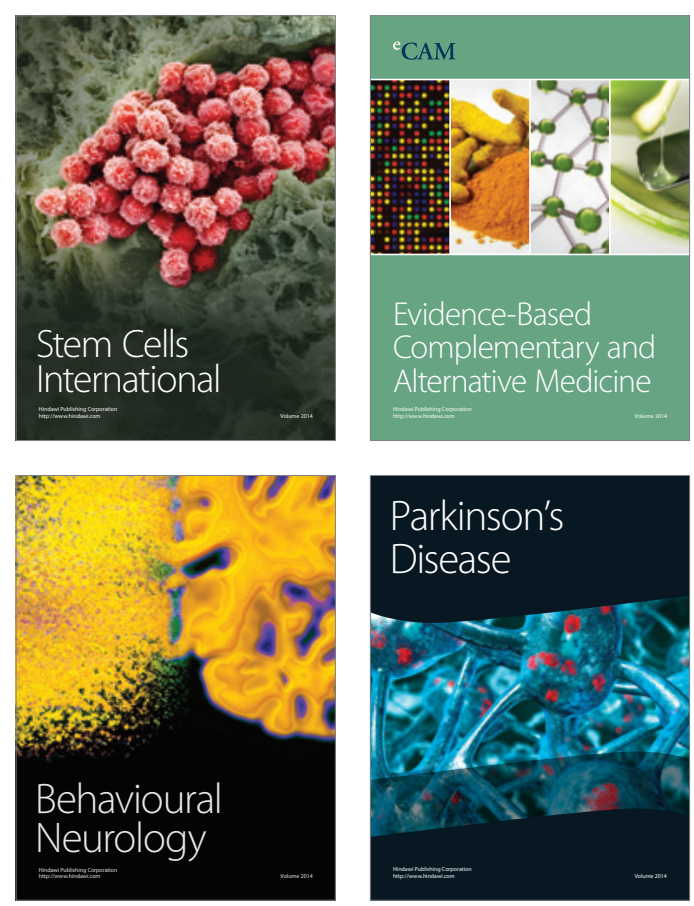

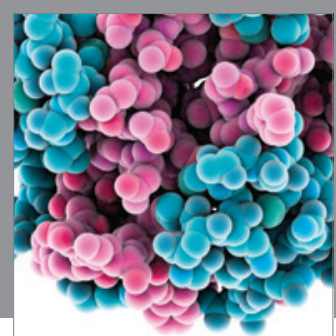

Journal of
Diabetes Research

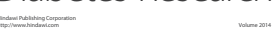

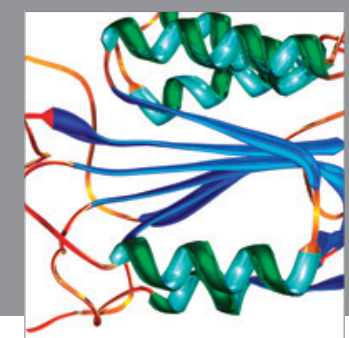

Disease Markers
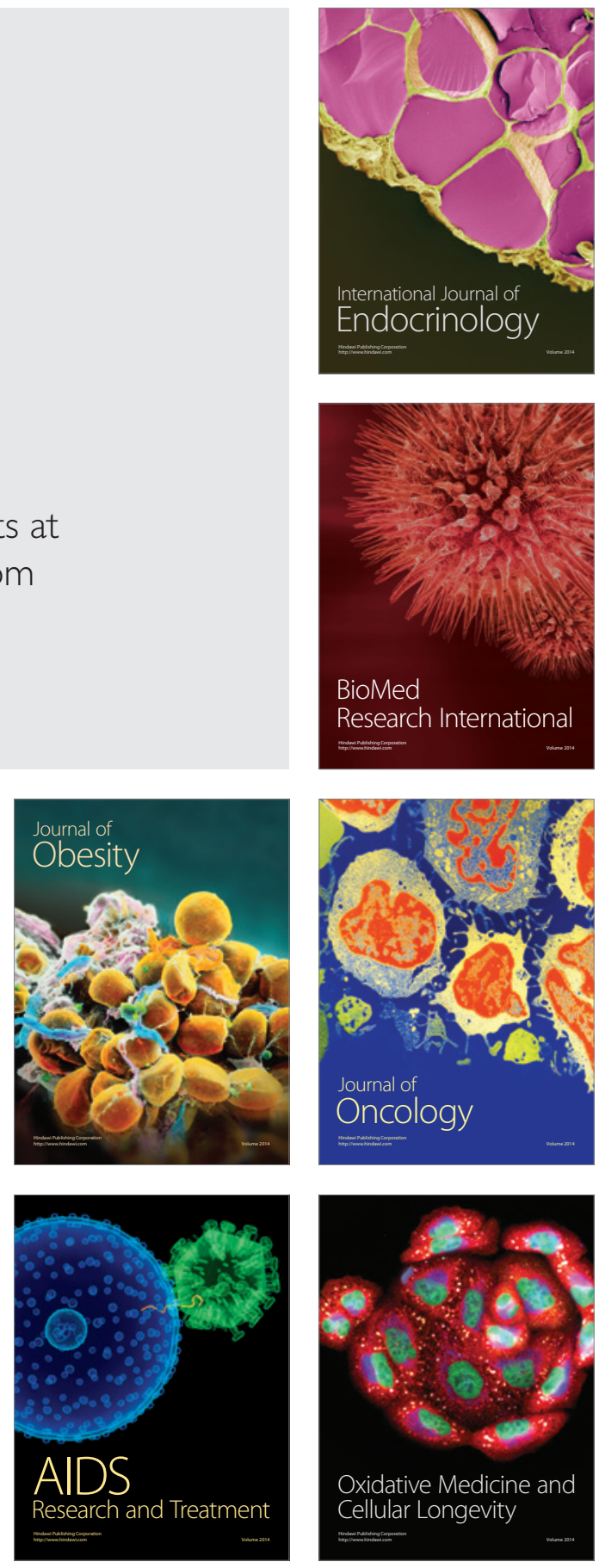